P-397

受傷 1 年後に胃捻転脱出をきたして発見された 外傷性左横隔膜ヘルニアの 1 例

市立吹田市民病院 外科

瀬下 巌, 横内 秀起

【目的】交通外傷時に見過ごされ， 1 年後に胃捻転脱出をきたして発見 された外傷性左横隔膜へルニアの 1 例を経験したので報告する.【症 例】 27 歳男性, オートバイ乗用中に自己転倒し左半身を強打, 肋骨亀 裂骨折と大腿部皮下血腫をきたしたが，保存的治療にて軽快．その後， 特に支障なく日常生活を送っていたが， 1 年 2 ケ月後に突然の心窩部 激痛で緊急入院．X線・CTにて，上下方向に捻転をきたした胃㧍よび 脾臓, 結腸, 大網の左胸腔内脱出を認めた。胃管を挿入し減圧したと ころ, 速やかに腹痛は解消し, X 線上, 胃の腹腔内還納を確認したが, 横隔膜上に陰影が残存した。胸腔内残存臓器の還納と横隔膜外傷性裂 孔の修復を目的として 2 週間後に手術を行った。当初胸腔鏡下に手術 を開始したが, 脾臟, 横行結腸, 大網が比較的小さい横隔膜の裂孔か ら大きく脱出し，大網が裂孔に一部に強固に癒着していたため, 開胸 手術に切り替えた。横隔膜の裂孔を切開して広げ，大網と裂孔の癒着 部を鋭的に剥離し, 脱出臓器を腹腔内に還納し, 横隔膜の裂孔および 切開部を縫合閉鎖して終了. 術後経過良好にて 6 ケ月後の現在再発な し.【結論】鈍的外傷による横隔膜ヘルニアは, 痛みや呼吸困難, 出血 徵候を伴い, 胸部 X 線上の異常陰影で受傷時に発見されることが多い が，横隔膜損傷部からの出血が軽微で自然に止血し，他の臟器損傷も 伴わない場合, 見過ごされる可能性がある. その場合, 徐々にもしく は突発的に脱出程度が進行し遅れて顕性化してくるので, 心窩部痛・ 不快感を訴え, X 線上, 横隔膜のラインが不鮮明な症例では, 受傷歴 があれば本疾患も疑って CT 検査で確認すべきであろう。

\section{P.399 鈍的外傷による乳糜胸の一例}

関東労災病院 呼吸器科

山本 健嗣, 田尻道彦, 山形 達史

乳糜胸は大きく外傷性と非外傷性に分類され，外傷性はさらに手術性 と非手術性に再分類される。外傷性は殆どが手術によるものであり, 鈍的外傷によるものは極めて稀である.今回我々は鈍的外傷後の乳糜 胸の一例を経験したので報告する。症例は 68 歳, 女性. 平成 16 年 8 月 9 日，階段にて転倒し腰背部打撲し当院受診. 胸部単純写真にて右 胁骨骨折を認めた。 その後近医にて follow up 中, 平成 16 年 10 月 1 日 右胸水貯留を認め, 入院, 胸腔ドレナージ施行. 乳び胸水を認め, 外 傷性乳び胸と㟝断.9日間の絶食にて改善し平成 16 年 10 月 22 日退院. 平成 16 年 11 月 26 日再診時, 乳び胸再発し 11 月 29 日当院紹介受診. 11 月 30 日当院入院し胸腔ドレナージ施行. 乳び胸水を認めた. 12 月 7 日胸腔鏡下胸管結禁術施行した．文献的考察を加えて報告する。
P-398

3 次救急として搬送された鋭的胸部外傷例の検 討

都立広尾病院 外科

横須賀 哲哉, 小林 利子

対象： 2002 年 6 月から 2004 年 11 月までの 30 ケ月間に当院に 3 次救 急として搬送された鋭的胸部外傷例, 14 例. 男性 12 例, 女性 2 例. 21 ～ 71 歳, 平均 39 歳. 受傷機転は刺創 12 例 (刺されたもの 7 例, 自殺 企図 3 例, 自分で䛊って刺したもの 2 例)。銃創 2 例 (ともに他人に撃 たれた)，治療：全 14 例中の 5 例で手術が行われた。 内訳は，刺創 12 例では, 手術が行われたのは 3 例（2 例は横隔膜損傷部の綘合, 1 例は 肺・心膜損傷部の縫合), 胸腔ドレナージを行ったが手術を要さなかっ たのが 5 例，局所麻酔下の創縫合のみが 4 例であった．銃創の 2 例は ともに手術となった（1 例は肺葉切除，1例は胸壁の止血のみ). 予後： 軽快退院が 11 例，不明が 2 例あり，ともに逃走した外国人（1例はド レーン留置のまま, 1 例は体表刺創の縫合後.）死亡は 1 例. 肺癌末期 患者の自殺企図で腹部の刺創もあったが，心肺停止後蘇生された。し かし意識レベル JCS 300 となり, 家族とも相談の末, ドレナージのみ 行った．考察：胸部の鋭的外傷は鈍的外傷に比べ手術が必要になるこ とが多い. 今回の検討例中には心・大血管損傷が含まれていないこと もあり，適切な対応により予後は良好であった。

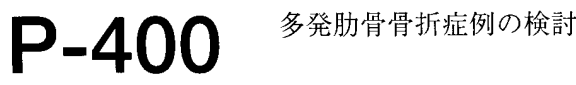

${ }^{1}$ 大津市民病院 呼吸器外科, ${ }^{2}$ 大津市民病院 心臟血管外科

戸田 省吾 ${ }^{1}$, 増田 慎介 ${ }^{2}$, 伊東 正文 ${ }^{2}$, 神吉 豊 ${ }^{2}$

【目的】多発肋骨症例の管理について検討する。【方法】2004 年 1 月 から 12 月までの 1 年間に経験した, 4 本以上の肋骨が骨折した多発肋 骨症例 9 例.【結果】年齢は 37 歳から 75 歳 (平均 58 歳), 男性 7 例. 女性 2 例. 胁骨骨折の本数は, 4 本 4 例 $\cdot 5$ 本 3 例 $\cdot 6$ 本 2 例. 3 例は 複数個所（最大 11 か所）で骨折していた，受傷理由は，交通事故 5 例・転落転倒 4 例．全例に血胸ないし気胸を合併していたが，緊張性 気胸を生じた例はなく, 当日のドレーン㨂入は 2 例のみで, 経過中に ドレーン挿入が必要となった症例が2例, 穿刺排液が必要となった症 例が 1 例, 他の症例は経過観察のみであった。 その他の合併損傷は, 肺挫傷 4 例 ・両鎖骨骨折 1 例 - 骨盤骨折 1 例 ・ 心夕ンポナーデ 1 例 · 外傷性クモ膜下出血 1 例（重複例を含む）。挿管管理は，無気肺のため 受傷後 2 日目から 1 週間行った 1 例のみであった４ 4 本計 11 か所で骨 折した症例は，骨折片が胸腔内に陥凹していたため手術を計画したが， 骨盤骨折が高度で側臥位がとれず断念したものの，胸郭動摇もきたさ ずに治癒した。この症例を含胁骨骨折は全例で保存的に経過観察可 能であった。 入院期間は 2 日から 50 日, 平均 18 日であったが, 入院 期間が長期となった 2 例も合併した他部位の骨折の治療のためであっ た. 全例社会復帰可能であった.【結論】2004 年の 1 年間に経験した多 発胁骨症例は, 全例保存的に経過観察可能であった。しかし, 一旦退 院したあとで血胸・心タンポナーデを生じてショック状態となった症 例があり，数ヶ月は厳重な観察が必要であると考える。 